\title{
A method for predicting the factor of safety of an infinite slope based on the depth ratio of the wetting front induced by rainfall infiltration
}

\author{
B.-G. Chae ${ }^{1}$, J.-H. Lee ${ }^{2}$, H.-J. Park ${ }^{2}$, and J. Choi ${ }^{1}$ \\ ${ }^{1}$ Korea Institute of Geoscience and Mineral Resources, 305-350 Daejeon, Republic of Korea \\ ${ }^{2}$ Dept. of Geoinformation Engineering, Sejong University, 147-747 Seoul, Republic of Korea \\ Correspondence to: H.-J. Park (hjpark@ sejong.ac.kr) and J. Choi (jhchoi@kigam.re.kr)
}

Received: 31 December 2014 - Published in Nat. Hazards Earth Syst. Sci. Discuss.: 28 January 2015

Revised: 20 July 2015 - Accepted: 3 August 2015 - Published: 18 August 2015

\begin{abstract}
Most landslides in Korea are classified as shallow landslides with an average depth of less than $2 \mathrm{~m}$. These shallow landslides are associated with the advance of a wetting front in the unsaturated soil due to rainfall infiltration, which results in an increase in water content and a reduction in the matric suction in the soil. Therefore, this study presents a modified equation of infinite slope stability analysis based on the concept of the saturation depth ratio to analyze the slope stability change associated with the rainfall on a slope. A rainfall infiltration test in unsaturated soil was performed using a column to develop an understanding of the effect of the saturation depth ratio following rainfall infiltration. The results indicated that the rainfall infiltration velocity due to the increase in rainfall in the soil layer was faster when the rainfall intensity increased. In addition, the rainfall infiltration velocity tends to decrease with increases in the unit weight of soil. The proposed model was applied to assess its feasibility and to develop a regional landslide susceptibility map using a geographic information system (GIS). For that purpose, spatial databases for input parameters were constructed and landslide locations were obtained. In order to validate the proposed approach, the results of the proposed approach were compared with the landslide inventory using a ROC (receiver operating characteristics) graph. In addition, the results of the proposed approach were compared with the previous approach used: a steady-state hydrological model. Consequently, the approach proposed in this study displayed satisfactory performance in classifying landslide susceptibility and showed better performance than the steady-state approach.
\end{abstract}

\section{Introduction}

Landslides in Korea, which are primarily caused by intense rainfall during the summer, are typically shallow landslides due to their shallow $(\leq 2 \mathrm{~m}$ ) failure planes. These shallow landslides are triggered by rainfall infiltration as well as a rise of the groundwater table (Cannon and Ellen, 1985; Aleotti, 2004). Therefore, the shallow landslides can be associated with the advance of a wetting front in the soil due to rainfall infiltration, which results in an increase in the water content and a reduction in matric suction in the soil. These processes may result in a decrease in the effective stress in the near-surface soil and may ultimately lead to slope failure (Rahardjo et al., 1995; Fourie, 1996; Ng and Shi, 1998).

Landslides in a given area can be triggered at various times under the same rainfall conditions due to variations in soil properties. Thus, it is necessary to analyze the relationships between soil properties and landslide occurrence while considering the physical thresholds involved in each case. Many studies have focused on the triggering of landslides as a function of various soil properties during rainfall. Such studies include landslide prediction in a regional area using a wetness index and infinite slope model. The wetness index, proposed by Beven and Kirkby (1979), has been used to indicate the degree of slope saturation while considering the geomorphologic properties of the slope. Based on steady-state recharge, the wetness index is related to the upslope contributing area. Shallow subsurface flow follows the topographic gradients, which means that the area contributing to flow at any point is a function of the specific catchment area as defined by the surface topography (Beven and Kirkby, 1979). 
In general, rainfall infiltrates the soil along a gravitational gradient and forms a perched water table in the soil. In the case of shallow landslides, these perched zones are typically caused by increases in volumetric water content and porewater pressure due to water infiltration from the surface. This infiltration induces saturation of the soil at a certain depth and time. Soil saturation can be expressed as a ratio of the saturated depth to the total thickness of soil at a given time, which is defined by the saturation depth ratio of the soil due to rainfall infiltration (Hammond et al., 1992). The saturation depth ratio indicates the portion of a given soil layer that is saturated. Because landslides generally occur in the saturated portion of the soil layer, it is possible to evaluate changes in slope stability based on the changes in the saturation depth ratio in a soil layer. Therefore, the saturation depth ratio and the changes in the water content of the soil can be used to predict landslides. The changes can be recognized by observing the behavior of the wetting front in the soil.

The wetting front advances downward in the soil from the ground surface as rainfall infiltrates, and the wetting condition of the soil changes for this reason. At this time, the velocity of the wetting front changes depending on the rainfall intensity and the rainfall infiltration capacity of the soil. The rainfall infiltration capacity determines the rainfall infiltration velocity, which is influenced by various soil parameters, such as the unit weight, porosity and mineral composition. If the volumetric water content and porewater pressure increase as the wetting condition of the soil layer changes, the matric suction consequently decreases and the slope fails with a sufficient decrease in the shear strength (Fredlund and Rahardjo, 1993; Muntohar and Liao, 2010). Therefore, understanding the behavior of the wetting front following infiltration of rainfall from the land surface and the saturation depth ratio will advance understanding of the triggering of landslides in the soil in a manner unlike that of conventional saturated soil theory. Accordingly, this study presents a landslide prediction method based on the wetting front, infiltration velocity and saturation depth ratio rather than a complex relationship between rainfall intensity and physical factors. Because the proposed method involves the relatively simple measurement of the wetting front, landslides can be predicted relatively easily based on the changes in the slope factor of safety with time as a function of the rainfall infiltration.

\section{Slope stability analysis based on the saturation depth ratio}

The infinite slope method is a method of slope stability analysis in which the length of the sliding plane is large relative to its depth and the sliding plane is assumed to follow a straight line parallel to the ground surface (Rahardjo et al., 1995; Crosta, 1998). In Korea, landslides occur due to rainfall; thus, rainfall infiltration into the surface soil layer acts as an important factor in landslide occurrence. Many weathered soils in Korea can be classified as silty sands or sands. These soils have a tendency to drastically lose shear strength when saturated and to be easily untangled in water (Lee and de Freitas, 1989; Kim et al., 2004). Therefore, rainfall infiltration is a major cause of shallow landslides on natural slopes underlain by these soil types.

Based on existing methods of infinite slope stability analysis, it is difficult to calculate the factor of safety of a slope based on variations in rainfall infiltration with time using the existing methods of infinite slope analysis. Accordingly, a modified equation of infinite slope analysis is proposed by applying the concept of the saturation depth ratio to analyze the slope stability changes in the amount and duration of rainfall on slopes with shallow failures. The modified equation of infinite slope stability analysis presented herein is based on the ratio of the density of water to the total density, which is not the unit weight of the soil, and the changes in the depth of the wetting front during the rainfall infiltration. In particular, the rainfall infiltration as a function of the rainfall duration is not considered in the existing infinite slope stability analysis equation, and thus, the changes in the factor of safety caused by this infiltration have been calculated based on the saturation depth ratio of rainfall infiltration on the depth of the soil layer. The wetting front is the boundary along which the soil gradually transitions from its initial unsaturated state to a state of saturation as the water content increases following rainfall infiltration (Kim et al., 2004). The wetting front plays an important role in identifying the cause of landslide triggering in an infinite slope model based on the actual infiltration characteristics due to rainfall. In addition, previous studies have been based on the water pressure $(\mu)$ acting on the shear surface, and the emphasis has been on the rise in groundwater levels rather than the rainfall infiltration characteristics. However, we do not have enough data to explain the triggering mechanism of landslides by the rise of the groundwater table or perched water table in Korea. Since shallow landslides are common in Korea, and the rainfall infiltration and the deepening of the wetting zone are important factors that cause shallow landslides (Rahardjo et al., 1995; Ng and Shi, 1998; Fourie et al., 1999; Kim et al., 2004), this study assumes that soil saturation by rainfall infiltration is one of the triggering factors of landslides in Korea. In this study, the wetting front depth $\left(D_{\mathrm{wf}}\right)$ in the soil layer accounts for rainfall infiltration and rainfall duration, and serves as the primary variable. In other words, a modified infinite slope stability analysis equation that enables a practical slope stability analysis has been proposed by considering rainfall characteristics, such as the amount and duration of rainfall, and the consequent variations in the wetting front.

The change in the wetting front induced by the rainfall infiltration pattern in the soil layer is shown in Fig. 1. 
The existing equation for calculating the factor of safety of an infinite slope is as follows (Hammond et al., 1992):

$\mathrm{FS}=\frac{c_{\mathrm{r}}+c_{\mathrm{S}}+\cos ^{2} \theta\left[\rho_{t} g\left(D-D_{\mathrm{w}}\right)+\left(\rho_{t} g-\rho_{\mathrm{w}} g\right) D_{\mathrm{w}}\right] \tan \phi}{D \rho_{t} g \sin \theta \cos \theta}$.

Here, $c_{\mathrm{r}}$ is the cohesion of plant roots $\left(\mathrm{N} \mathrm{m}^{-2}\right), c_{\mathrm{S}}$ is the cohesion of soil $\left(\mathrm{N} \mathrm{m}^{-2}\right), \theta$ is the slope gradient $\left(^{\circ}\right), \rho_{t}$ is the soil density $\left(\mathrm{kg} \mathrm{m}^{-3}\right), \rho_{\mathrm{W}}$ is the density of water $\left(\mathrm{kg} \mathrm{m}^{-3}\right), g$ is the acceleration due to gravity $\left(9.81 \mathrm{~m} \mathrm{~s}^{-2}\right), D$ is the depth of the soil layer $(m), D_{\mathrm{w}}$ is the vertical height of the water table $(m)$ and $\phi$ is the internal friction angle of the soil $\left({ }^{\circ}\right)$.

If the physical properties of the soil layer are derived based on Fig. 1, the thickness of the soil layer is measured perpendicular to the bedrock, which has a practical effect on the failure volume during slope failure and shear strength at the time of failure. Furthermore, rainfall infiltration occurs in the depth direction $(D)$, and thus, its relationship with the soil layer thickness $(h)$ is as follows:

$h=D \cos \theta$.

Because rainfall infiltrates in the depth direction, rainfall infiltration is conceptually the same as the advance of the wetting front. The wetting front at the time of rainfall infiltration is located where the volumetric water content attains a maximum value. The maximum value of the volumetric water content between the ground surface and the wetting front means that the soil is saturated. Since the infinite slope stability analysis for a deep-seated landslide has a basic assumption that soil saturation is caused by the rise of the groundwater table, the height of the groundwater table from the potential sliding plane in the soil layer should be considered. In the case of a shallow landslide, however, it is mostly related to soil saturation by rainfall infiltration from the ground surface rather than rise of the groundwater table (Kim et al., 2004). Therefore, this study considers the saturation thickness of the soil between the ground surface and the wetting front by rainfall infiltration under the shallow landslide conditions. The location of the wetting front is measured using a water content sensor or porewater pressure sensor at a fixed depth in the soil layer. The saturation depth ratio $(H)$ in a soil layer is given by the equation below and is the ratio between the depth of the saturated soil layer, $D_{\mathrm{wf}}$, and the depth of the soil layer.

$H=\frac{D_{\mathrm{wf}}}{D}$

The saturation depth ratio varies with time because it is affected by the rainfall duration and similar factors.

Although the cohesion of the soil includes the effects of plant roots, here, it is taken as only the primary cohesion $(C)$ because there are variations in the types and depths of plant roots. To this end, the practical cohesion of the soil $(C)$ is derived using the equation shown below and is based on the cohesion due to plant roots $\left(c_{\mathrm{r}}\right)$ and the soil itself $\left(c_{\mathrm{s}}\right)$ as well

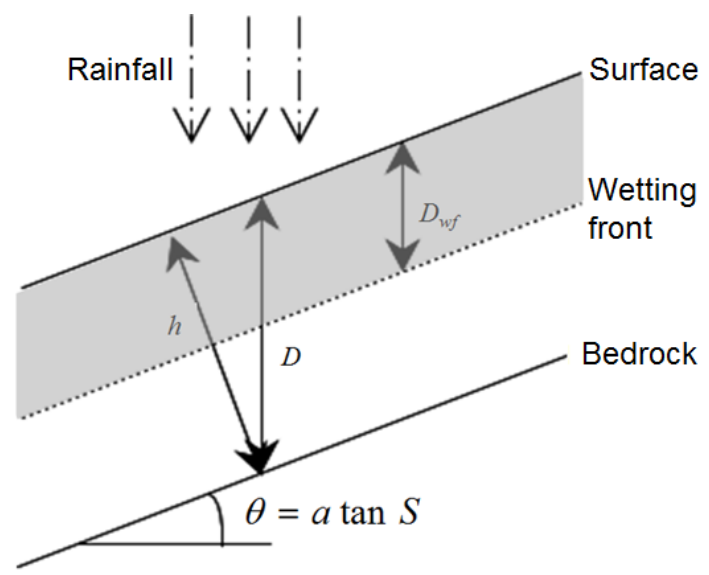

Figure 1. Schematic figure showing the concept of the wetted depth ratio considering a wetting front in the soil.

as the soil thickness, bulk density and gravitational acceleration.

$C=\frac{c_{\mathrm{r}}+c_{\mathrm{s}}}{h \rho_{t} g}$

Here, $C$ is dimensionless and is the ratio of the cohesion and the weight of the soil layer.

In addition, the density of the soil changes with changes in the water content due to rainfall infiltration, and thus, the ratio of the water density to the bulk density is given by the following relationship:

$\gamma=\frac{\rho_{\mathrm{w}}}{\rho_{t}}$.

Equations (2)-(5), which provide the substitutions for the physical properties of the soil layer in Eq. (1), yield the following derivation:

$$
\begin{aligned}
\mathrm{FS} & =\frac{c_{\mathrm{r}}+c_{\mathrm{S}}+\cos ^{2} \theta[A] \tan \phi}{D \rho_{t} g \sin \theta \cos \theta} \\
& =\frac{c h \rho_{t} g}{D \rho_{t} g \sin \theta \cos \theta}+\frac{\cos ^{2} \theta[A] \tan \phi}{D \rho_{t} g \sin \theta \cos \theta} \\
& =\frac{c}{\sin \theta}+\frac{\cos ^{2} \theta\left[\rho_{t} g D-\rho_{\mathrm{w}} g D_{\mathrm{wf}}\right] \tan \phi}{D \rho_{t} g \sin \theta \cos \theta} \\
& =\frac{c}{\sin \theta}+\frac{\rho_{t} g D \cos ^{2} \theta \tan \phi}{D \rho_{t} g \sin \theta \cos \theta}-\frac{\rho_{\mathrm{w}} g D_{\mathrm{wf}} \cos ^{2} \theta \tan \phi}{D \rho_{t} g \sin \theta \cos \theta} .
\end{aligned}
$$

Here, $A$ denotes $\left[p_{t} g\left(D-D_{\mathrm{wf}}\right)+\left(\rho_{t} g-\rho_{\mathrm{w}} g\right) D_{\mathrm{wf}}\right]$.

Equation (6) can reflect the substitutions of Eqs. (3) and (5) and can be rewritten as follows:

$$
\begin{aligned}
\mathrm{FS} & =\frac{c}{\sin \theta}+\frac{\cos \theta \tan \phi}{\sin \theta}-\frac{\cos \theta \tan \phi H(t) \gamma}{\sin \theta} \\
& =\frac{c+\cos \theta(1-H(t) \gamma) \tan \phi}{\sin \theta} .
\end{aligned}
$$

Here, $C$ is the cohesion ratio, $\theta$ is the slope angle $\left(^{\circ}\right), \phi$ is the internal friction angle of the soil $\left(^{\circ}\right), \gamma$ is the ratio of the water density to the bulk soil density and $H(t)$ is the saturation 
depth ratio as a function of time. Because Eq. (7) accounts for the change in saturated state following rainfall infiltration from the ground surface, which is not the conventional concept of a rise in groundwater, it is not based on measurements of the ground water level.

In Korea, rainfall infiltration has a greater effect on landslide occurrence than the ground water level does. In other words, the failure progresses as a form of shallow failure as the unsaturated soil layer attains a saturated state following the infiltration of rainfall. Therefore, it is more appropriate to consider the saturation depth ratio $H(t)$ to explain variations in the wetting front than changes in the ground water level in the infinite slope model. The rainfall infiltration depth ratio is also reasonably useful in analyzing the stability of a slope as a function of rainfall because this ratio may be correlated with such parameters as the amount, duration and type of rainfall.

The saturation depth ratio $H(t)$ as a function of time can be calculated using Eq. (8). $H(t)$ is the ratio of the saturated soil layer depth due to the infiltration of the wetting front to the total depth of the soil layer, and its value ranges from 0 to 1 .

$H_{i}(t)=\frac{D_{i}(t)}{D}: \quad 0<H_{i}(t) \leq 1$

Here, $D$ is the depth of the unsaturated soil layer, and $D_{i}(t)$ is the wetting front depth of the $i$ th point (i.e., the saturation depth).

The factor of safety based on variations in the saturation depth ratio with time as given by Eq. (7) directly accounts for the rainfall and saturated state of the soil layer with time, in contrast with the existing slope stability models, which account for only the porewater pressure. Therefore, this equation is valid for the conditions of shallow landslides such as those that occur in Korea, where the saturation of the soil layer by downward movement of the wetting front from the ground surface is dominant (Park et al., 2011).

\section{Calculation of the rainfall infiltration velocity in unsaturated weathered soils using column tests}

In this study, a rainfall infiltration test in the unsaturated soil was performed using a column to better understand the effect of the saturation depth ratio following rainfall infiltration. We attempted to measure the rainfall infiltration velocity as a function of rainfall conditions and soil layer conditions to calculate the saturation depth ratio of the soil and to identify the variations in the factor of safety with time in accordance with Eq. (7), as explained in the previous section.

\subsection{Sampling and column test devices}

In this study, rainfall infiltration characteristics were analyzed using weathered granite soil, which is the typical weathered soil involved in landslides in Korea. A sample
Table 1. Physical properties of the weathered soils.

\begin{tabular}{llc}
\hline Soil property (unit) & Symbol & $\begin{array}{c}\text { Weathered } \\
\text { granite } \\
\text { soil }\end{array}$ \\
\hline Specific gravity & $G_{\mathrm{S}}$ & 2.570 \\
Wet density $\left(\mathrm{g} \mathrm{cm}^{-3}\right)$ & $w_{t}$ & 1.570 \\
Max. dry density $\left(\mathrm{g} \mathrm{cm}^{-3}\right)$ & $w_{\mathrm{dmax}}$ & 1.380 \\
Dry density $\left(\mathrm{g} \mathrm{cm}^{-3}\right)$ & $w_{\mathrm{d}}$ & 1.210 \\
Min. dry density $\left(\mathrm{g} \mathrm{cm}^{-3}\right)$ & $w_{\mathrm{dmin}}$ & 1.040 \\
Moisture content $(\%)$ & $w$ & 30.000 \\
Effective particle size $(\mathrm{mm})$ & $D_{10}$ & 0.100 \\
$D_{30}$ particle size $(\mathrm{mm})$ & $D_{30}$ & 0.250 \\
$D_{60}$ particle size $(\mathrm{mm})$ & $D_{60}$ & 0.600 \\
Uniformity coefficient & $C_{\mathrm{u}}$ & 6.000 \\
Coefficient of curvature & $C_{\mathrm{c}}$ & 1.000 \\
\hline
\end{tabular}

of weathered granite soil was collected from Sangju, in the Gyeongbuk area, where approximately 400 landslides occurred in August 1998. The topography of this region is mountainous, and quartz porphyry, granite porphyry and granitic gneisses underlie most of the region, as shown in Fig. 2. The granites include the Jurassic Boeun granite and a biotite hornblende granite. Their respective corresponding weathered soils differ substantially in terms of their organic components and particle composition. The quartz porphyry is located in the northern part of the study area, where few landslides occurred because the minerals are resistant to weathering. However, many landslides occurred in the granitic areas, where the soil is relatively thick, particularly in the low-lying areas. Although landslides occurred throughout the area, they occurred at a greater frequency in the areas underlain by granite around Hwaseo-myeon. Therefore, samples were collected from the granitic area where landslides were concentrated.

In the landslides in the Sangju area, the upper soil layer was composed of colluvial soil, and the residual soil was confined to the contact with the bedrock, and thus, a relatively shallow failure with a depth of less than $1 \mathrm{~m}$ was typical. The physical properties and particle size distributions of the weathered soil are shown in Table 1 and Fig. 3 .

The equipment for the unsaturated soil column testing consisted primarily of an artificial rainfall device, a soil column and a sensor unit and data acquisition device (Fig. 4). The artificial rainfall device supplied water from a water storage tank to an artificial rainfall distribution device, which delivered a constant flow using a controlled peristaltic pump. The water supplied in this manner created infiltration water by contacting the soil inside the column through the tube of the artificial rainfall distribution device, and the infiltration water infiltrated the soil column for eventual discharge through the outlet at the bottom of the soil column. The soil column had an inner diameter of $33 \mathrm{~cm}$, an outer diameter of $35 \mathrm{~cm}$ and a height of $50 \mathrm{~cm}$. Sensors designated TDR-1 through TDR- 


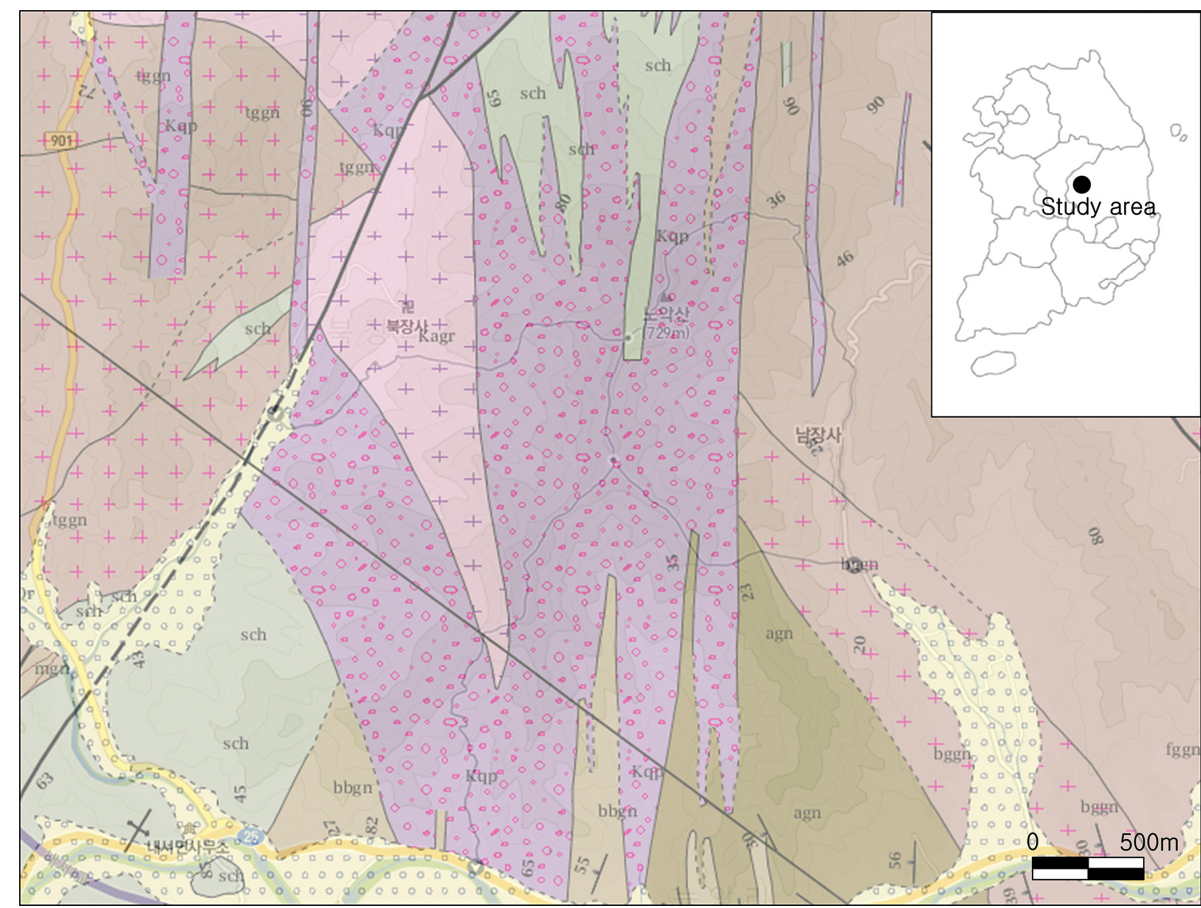

Figure 2. Study area. Kqp: granite porphyry, Kagr: alkali granite, tggn: hornblende granitic gneiss, agn: aplitic gneiss, Qr: river deposits and sch: schist complex.

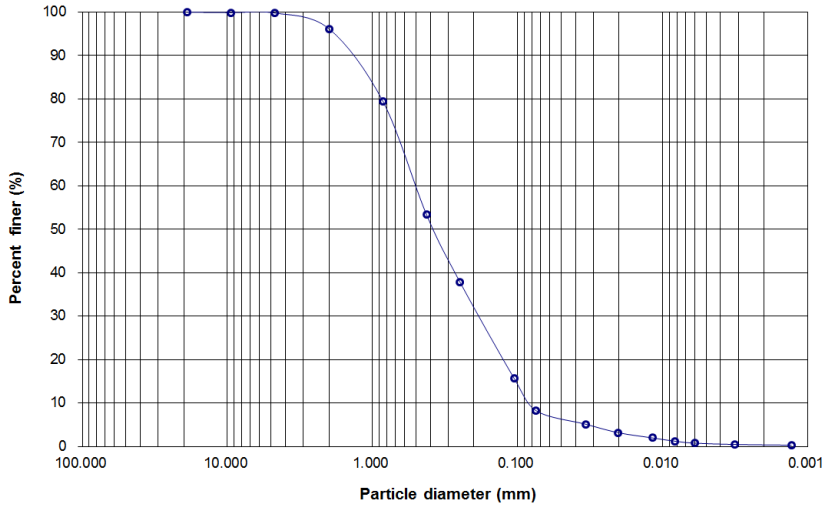

Figure 3. Grain size distribution of the weathered granite soil.

5 were inserted for water content measurements at depths of $5,15,25,35$ and $45 \mathrm{~cm}$ from the top of the column. Tensiometers designated Tensiometer-1 through Tensiometer-3 were inserted at depths of 10,30 and $40 \mathrm{~cm}$. The measured amounts of artificial rainfall were automatically saved to a computer at fixed time intervals using the TDR (time domain reflector) sensors for the water content measurement and the tensiometers.

Time domain reflector (TDR) sensors are designed to measure the volumetric water content of a medium based on the difference in permittivity between soil and water. In other words, the water content of soil can be indirectly measured from a correlation with measured water content after measuring the traveling time of an electromagnetic wave from an object that has an electric discontinuity. The TDR water content measurement sensor used in this study was the CS616 from Campbell. The controlled-volume pump used in the study was the Masterflex from L/S Cole-Parmer.

\subsection{Test methods}

In this study, testing was performed by measuring the sample and rainfall conditions and other factors that can affect the rainfall infiltration velocity to analyze the rainfall infiltration characteristics of unsaturated soil. The sample was completely dried for $24 \mathrm{~h}$ at $104{ }^{\circ} \mathrm{C}$ in a dryer oven. After examining the field unit weight values and the results of the compaction tests, the soil was remolded to three unit weights, including the minimum unit weight of $1.10 \mathrm{~g} \mathrm{~cm}^{-3}$ that enabled molding in the column, the dry unit weight in the field of $1.21 \mathrm{~g} \mathrm{~cm}^{-3}$ and the maximum dry unit weight of $1.35 \mathrm{~g} \mathrm{~cm}^{-3}$. The samples in the column were molded to be appropriate for the target unit weight by performing consolidation after slicing a sample with a height of $50 \mathrm{~cm}$ into 10 layers of $5 \mathrm{~cm}$ each. Consolidation of the soil sample was performed by vibrating the column with a rubber mallet and by dropping a weight with a diameter of $15 \mathrm{~cm}$ and mass of $5 \mathrm{~kg}$.

For the rainfall intensity measurements of this study, the total rainfall was calculated by converting the rainfall intensity to the rainfall amount per hour, as given by the equation 
(a)

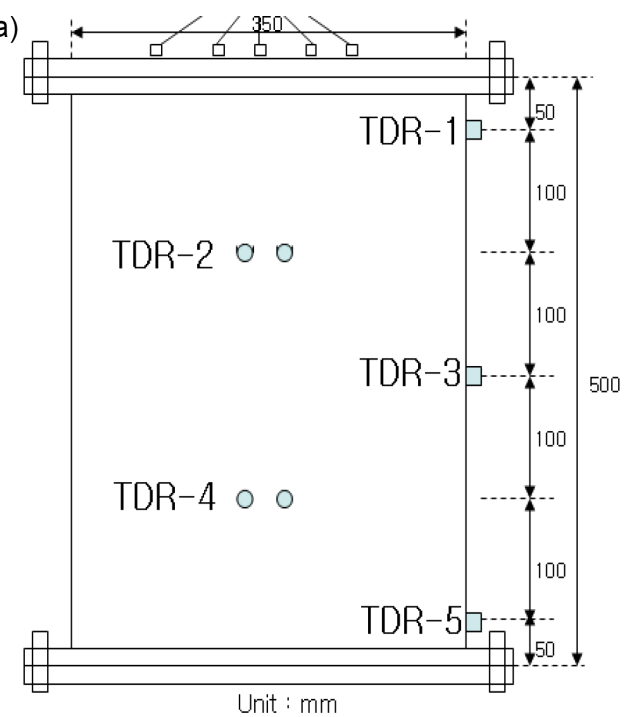

(b)

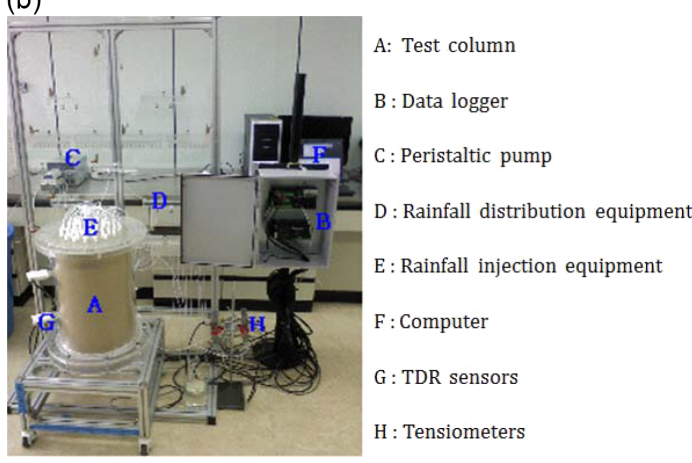

Figure 4. Unsaturated soil column test equipment. (a) Schematic description of the soil column and (b) composition of the column test equipment. A: soil column, B: peristaltic pump, C: rainfall distribution unit, D: rainfall injection tubes, E: water content sensors, F: tensiometer, G: data logger and H: computer.

below and after estimating the amount of artificial rainfall per minute (RPM) using the controlled peristaltic pump (Park et al., 2011).

$i=r /\left(\pi d^{2} / 2\right)$

$R=i \times t_{\mathrm{rd}}$

Here, $i$ is the rainfall intensity $\left(\mathrm{mm} \mathrm{min}^{-1}\right), r$ is the rainfall per minute $\left(\mathrm{mL}=\mathrm{cc}=\mathrm{cm}^{3} \mathrm{~min}^{-1}\right), d$ is the column diameter $\left(\mathrm{cm}^{2}\right), R$ is the total amount of rainfall $(\mathrm{mm})$ and $t_{\mathrm{rd}}$ is the rainfall duration $(h)$.

The artificial rainfall intensity was set at values of 20 and $50 \mathrm{~mm} \mathrm{~h}^{-1}$, which are the warning thresholds of the Korea National Emergency Management Agency. The total amount of rainfall during the testing was $200 \mathrm{~mm}$. This value was selected because domestic landslides frequently occur when the amount of continuous rainfall exceeds $200 \mathrm{~mm}$ (Kim and Chae, 2009), and the accumulated rainfall amount was
$280 \mathrm{~mm}$ during the landsliding of August 1998 in the area of Hwaseo-myeon, Sangju, which is where the samples were collected (Table 2). To reproduce the effects of drainage followed by basal discharge of water from the slope, the artificial rainfall was made to drain through the artificial outlet at the bottom of the column by injecting artificial rainfall into the column (Fig. 4a).

The rainfall infiltration velocity as a function of soil conditions and rainfall intensity was calculated as follows:

$V=\frac{L}{t_{\text {iwd }}}$.

Here, $V$ is the artificial rainfall velocity $\left(\mathrm{cm} \mathrm{s}^{-1}\right), t_{\text {iwd }}$ is the infiltration water detection time (sec), and $L$ is the depth from the upper column to each TDR sensor for the water content measurements $(\mathrm{cm})$.

The rainfall infiltration velocity per unit length was calculated by setting $5 \mathrm{~cm}$ in the case of TDR-1 and $10 \mathrm{~cm}$ in the cases of the remaining sensors. The rainfall infiltration velocity was calculated using Eq. (11) by measuring the infiltration detection time based on the water content measurement obtained from the TDR sensors at the various depths to average the rainfall infiltration velocity at each sensor on this basis.

The column test was performed until the drainage stopped or until $20 \mathrm{~h}$ had elapsed after stopping the rainfall in the event that drainage did not occur. The residual volumetric water content was measured after the test by subtracting the volumetric water content measured at the start of the test from the volumetric water content measured at the end of the test.

Although the artificial rainfall intensity and rainfall amount could be controlled and calculated using the controlled peristaltic pump, the total amount of water injected into the soil was calculated by summing the residual volumetric water content in the soil and the amount of drained water to verify the total amount of rainfall actually injected into the soil column. The amount of drained water corresponds to the water flows down the slope along the base of the soil layer, as explained above. The amount of drained water and the amount of water introduced into the top of the column were converted to the rainfall amount using Eqs. (9) and (10) after measuring the weights. As a result of the verification, each error margin occurred as shown in Table 3 based on the target rainfall amount of $200 \mathrm{~mm}$. The error margin during the tests was a maximum of $2 \mathrm{~mm} \mathrm{~h}^{-1}$, which is low compared to the total rainfall, and the effect on the test result is thought to be minor. This error margin is believed to have originated in the slight error margins associated with the testing device where the rainfall intensity was not being precisely controlled. Because errors associated with the molding may be included in the rainfall intensity control and target unit weight, the testing was performed three times to ensure the reliability of the test result. 
Table 2. Test conditions of the weathered soil.

\begin{tabular}{lcccc}
\hline $\begin{array}{l}\text { Test } \\
\text { conditions }\end{array}$ & $\begin{array}{c}\text { Unit weight } \\
\text { of soil } \\
\left(\mathrm{g} \mathrm{cm}^{-3}\right)\end{array}$ & $\begin{array}{c}\text { Rainfall } \\
\text { intensity } \\
\left(\mathrm{mm} \mathrm{h}^{-1}\right)\end{array}$ & $\begin{array}{c}\text { Rainfall } \\
\text { duration } \\
(\mathrm{h})\end{array}$ & $\begin{array}{c}\text { Porosity } \\
(\%)\end{array}$ \\
\hline $\mathrm{GrC} 1$ & 1.10 & 20 & 10 & 57.3 \\
$\mathrm{GrC} 2$ & 1.21 & 20 & 10 & 53.0 \\
$\mathrm{GrC} 3$ & 1.35 & 20 & 10 & 47.6 \\
$\mathrm{GrC} 4$ & 1.10 & 50 & 4 & 57.3 \\
GrC5 & 1.21 & 50 & 4 & 53.0 \\
GrC6 & 1.35 & 50 & 4 & 47.6 \\
\hline
\end{tabular}

\subsection{Analysis of the test results}

In this study, we analyzed rainfall infiltration characteristics and changes in infiltration velocity by way of continuous rainfall simulation through an unsaturated soil column (Figs. 5 and 6). The maximum volumetric water content in each test condition was indicated by the average of three replicate tests, and the maximum volumetric water content is the maximum value measured due to the increase in the maximum volumetric water content as the artificial rainfall was injected into the soil layer. The volumetric water content maintains a maximum value once the soil reaches saturation (Green and Ampt, 1911; Kim et al., 2012), and the rainfall infiltration velocity and soil saturation velocity can be determined if the time required for the soil to reach the maximum volumetric water content is measured. Through this process, the change in the saturation depth ratio of the soil layer with time can be determined. As shown in Figs. 5 and 6, the maximum volumetric water content was 28.7-40.8 and $32.7-39.4 \%$ in samples $\mathrm{GrC} 1$ and $\mathrm{GrC} 4$, respectively, which had unit weights of $1.10 \mathrm{~g} \mathrm{~m}^{-3}$. Samples $\mathrm{GrC} 2$ and $\mathrm{GrC} 5$, which had unit weights of $1.21 \mathrm{~g} \mathrm{~m}^{-3}$, had a maximum volumetric water content of 30.3-40.1 and 34.4-38.5\%, respectively. Samples GrC3 and GrC5, which had unit weights of $1.35 \mathrm{~g} \mathrm{~m}^{-3}$, had a maximum volumetric water content of $35.5-38.7$ and $37.2-40.0 \%$, respectively. The maximum volumetric water content increases with greater unit weights of the soil. In this study, the bottom of the soil column was opened to drain infiltrated rainfall into the soil. Therefore, the infiltrated rainfall can be drained more in soil with lower unit weight because it has more voids and faster infiltration or flow velocity of rainwater in the column. In the case of a soil condition of higher unit weight, rainwater is drained less than in soil with lower unit weight because of fewer voids and slower flow velocity of rainwater. Therefore, soil with higher unit weight contains more water in the column and the maximum volumetric water content is higher than in soil with lower unit weight (Table 3 ). In addition, the maximum volumetric water content was 28.7-40.8, 30.3-40.1 and $35.5-38.7 \%$ in samples $\mathrm{GrC} 1, \mathrm{GrC} 2$ and $\mathrm{GrC} 3$, respectively, under conditions of a rainfall intensity of $20 \mathrm{~mm} \mathrm{~h}^{-1}$. The maximum volumetric water content was $32.7-39.4$, 34.4-
Table 3. Amount of the injected water into the soil column.

\begin{tabular}{lcccc}
\hline $\begin{array}{l}\text { Test } \\
\text { conditions }\end{array}$ & $\begin{array}{c}\text { Amount of } \\
\text { residual } \\
\text { water }(\mathrm{mm})\end{array}$ & $\begin{array}{c}\text { Amount of } \\
\text { drained } \\
\text { water }(\mathrm{mm})\end{array}$ & $\begin{array}{c}\text { Amount of } \\
\text { overflowed } \\
\text { water }(\mathrm{mm})\end{array}$ & $\begin{array}{c}\text { Total amount } \\
\text { of water } \\
(\mathrm{mm})\end{array}$ \\
\hline $\mathrm{GrC} 1$ & 144.0 & 69.0 & 0.0 & 213.0 \\
$\mathrm{GrC} 2$ & 164.0 & 63.0 & 0.0 & 227.0 \\
$\mathrm{GrC} 3$ & 175.0 & 35.0 & 0.0 & 210.0 \\
$\mathrm{GrC} 4$ & 153.2 & 66.4 & 0.0 & 219.6 \\
$\mathrm{GrC5}$ & 169.6 & 14.8 & 0.0 & 184.4 \\
GrC6 & 178.8 & 22.4 & 0.0 & 201.2 \\
\hline
\end{tabular}

38.5 and $37.2-40.0 \%$ in samples $\mathrm{GrC} 4, \mathrm{GrC} 5$ and $\mathrm{GrC} 6$, respectively, under conditions of a rainfall intensity condition of $50 \mathrm{~mm} \mathrm{~h}^{-1}$. Notably, the volumetric water content was high when the rainfall intensity was high. This trend is thought to occur because a great deal of injected rainfall accumulates without flowing to the bottom of the soil layer by gravity when rainfall exceeds the draining ability of rainfall in the soil layer, and a considerable amount of rainfall is injected into the soil layer as the rainfall intensity increases.

The volumetric water content tends to increase with increasing soil depth. The maximum volumetric water content was $28.7-38.9 \%$ at TDR-1, which was at a $5 \mathrm{~cm}$ depth, and $38.5-40.7 \%$ at TDR-5, which was at a $45 \mathrm{~cm}$ depth. This pattern is related to the rainfall infiltration velocity, which tends to decrease with increasing soil depth. The amount of accumulated rainfall increases with increases in the rainfall duration (Park et al., 2011).

The residual volumetric water contents measured at the end of the test and the corresponding rainfall intensity conditions and soil unit weights are shown in Fig. 7. With soil unit weights of $1.10,1.21$ and $1.35 \mathrm{~g} \mathrm{~cm}^{-3}$, the residual volumetric water contents were $23.9-30.5,26.4-32.7$ and 30.1$35.2 \%$, respectively, under a rainfall intensity of $20 \mathrm{~mm} \mathrm{~h}^{-1}$. The corresponding values were higher, i.e., 23.4-30.6, 23.635.7 and $30.3-35.7 \%$, respectively, under a rainfall intensity of $50 \mathrm{~mm} \mathrm{~h}^{-1}$; the residual volumetric water contents clearly increase with increasing soil unit weights (Fig. 7). The explanation for this correlation between residual volumetric water content and soil unit weight at a constant rainfall intensity is the rapid discharge from the column with a greater effective porosity, which is associated with a lower soil unit weight (Kim et al., 1996). The residual volumetric water contents at a rainfall intensity of $20 \mathrm{~mm} \mathrm{~h}^{-1}$ and a soil unit weight of $1.10 \mathrm{~g} \mathrm{~cm}^{-3}$ was $23.9-30.5 \%$, which is similar to the value of $23.4-30.6 \%$ at a $50 \mathrm{~mm} \mathrm{~h}^{-1}$ rainfall intensity. In addition, similar residual volumetric water contents were observed at different rainfall intensities regardless of whether the unit weight of soil was 1.21 or $1.35 \mathrm{~g} \mathrm{~cm}^{-3}$. These findings illustrate that the residual volumetric water content varies depending on the unit weight of soil.

The average rainfall infiltration velocity under each test condition was also calculated based on the change in the measured volumetric water content (Fig. 8). As shown in 
(a) $\mathrm{GrC1}$

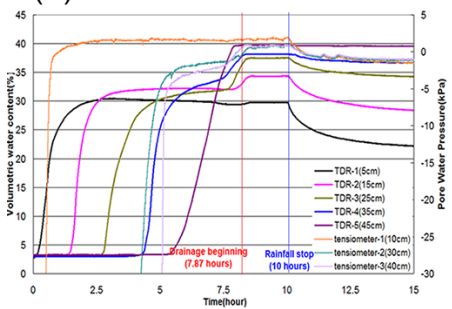

(b) $\mathrm{GrC} 2$

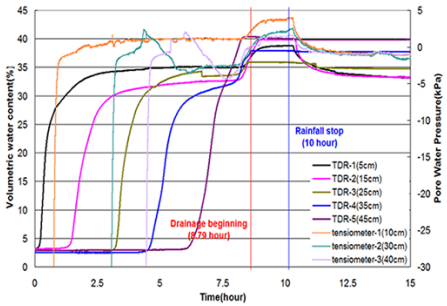

(c) $\mathrm{GrC} 3$

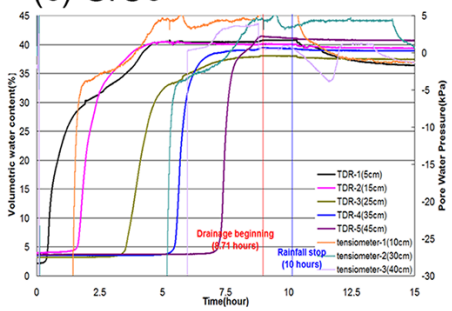

(d) $\mathrm{GrC} 4$

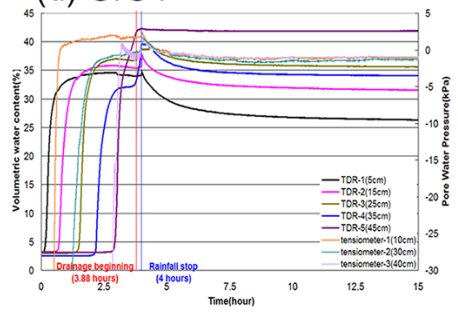

(e) GrC5
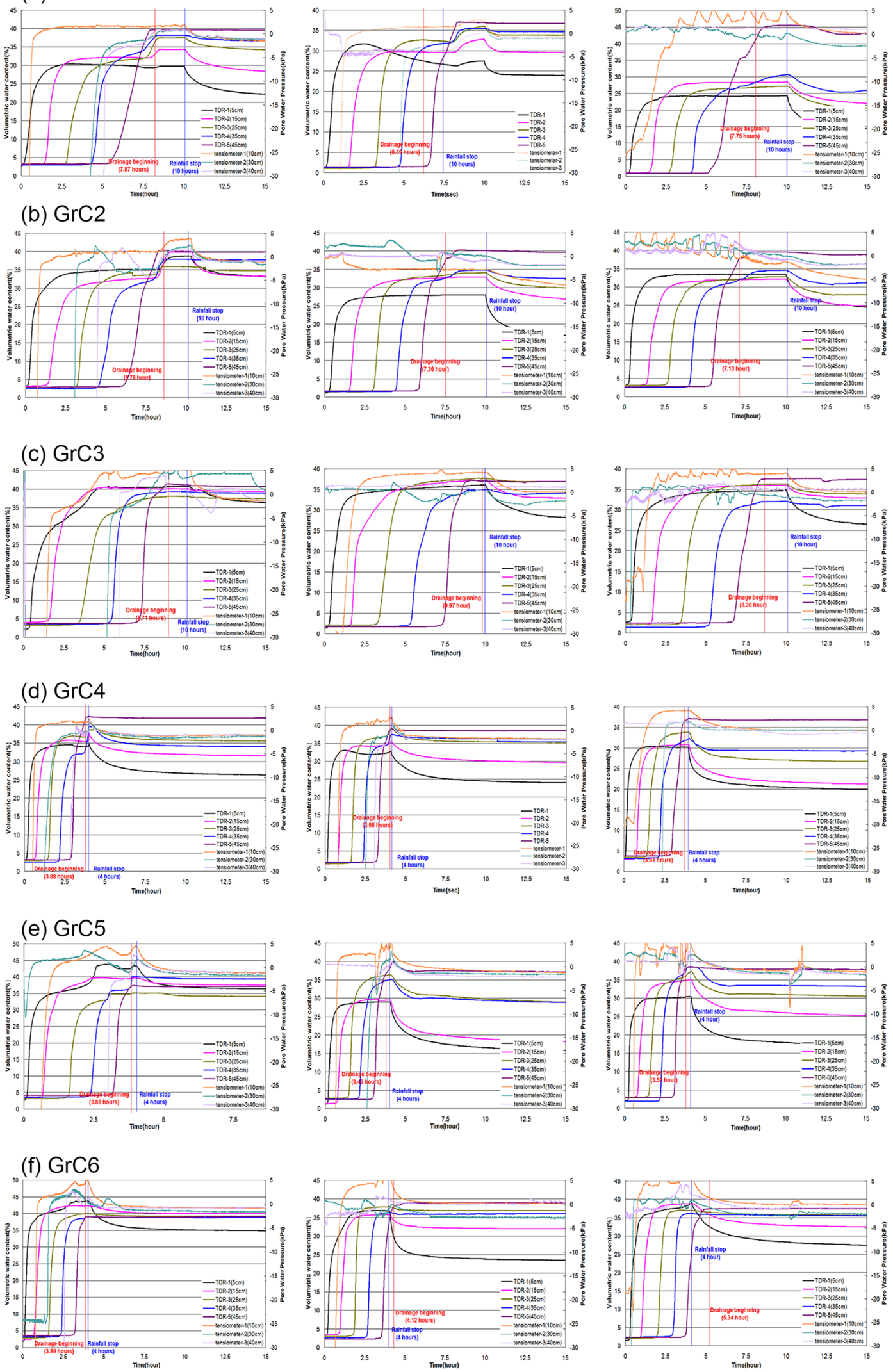

Figure 5. Volumetric water contents of the weathered granite soil in each test condition. (a) $\mathrm{GrC} 1$, (b) $\mathrm{GrC} 2$, (c) $\mathrm{GrC} 3$, (d) $\mathrm{GrC} 4$, (e) $\mathrm{GrC5}$ and (f) GrC6. 


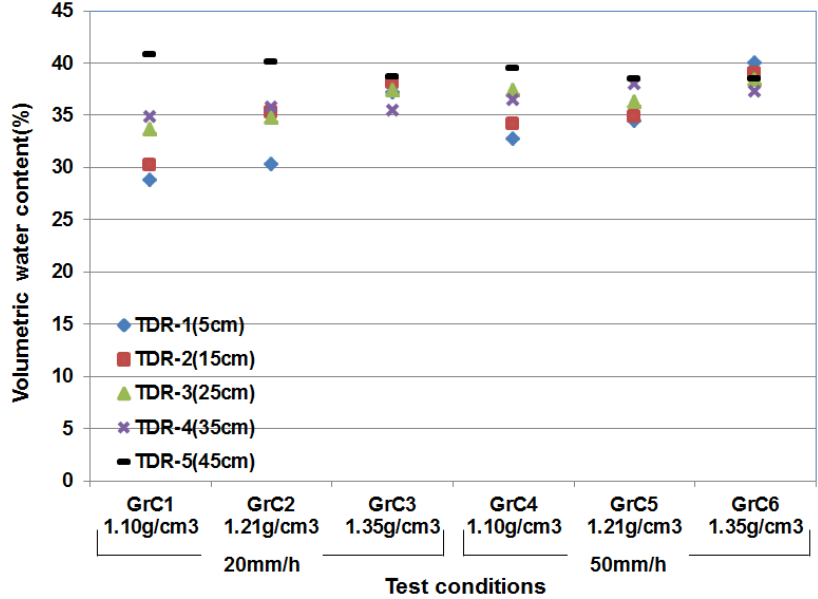

Figure 6. Maximum volumetric water content under each rainfall and unit weight soil condition at each depth.

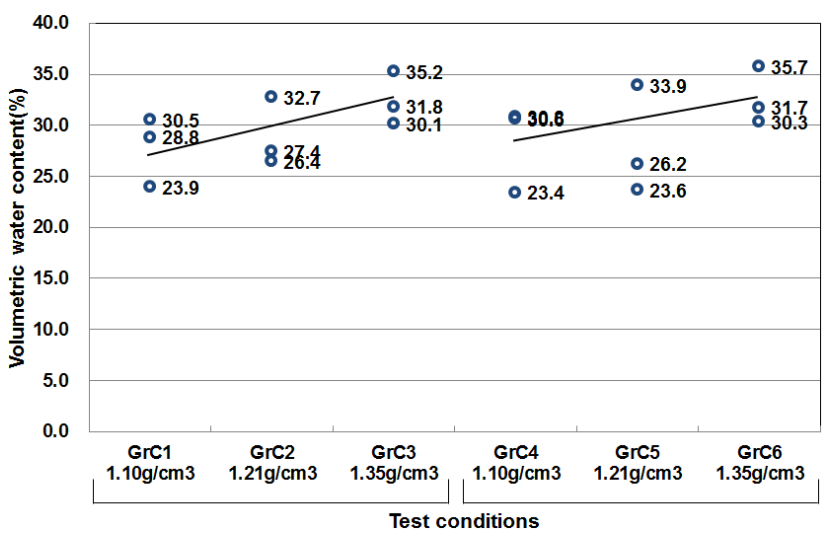

Figure 7. Residual volumetric water content of weathered granite soil.

Fig. 8a, the rainfall infiltration velocity was $2.143 \times 10^{-3}$, $2.060 \times 10^{-3}$ and $1.691 \times 10^{-3} \mathrm{~cm} \mathrm{~s}^{-1}$ when the unit weight of soil was $1.10,1.21$ and $1.35 \mathrm{~g} \mathrm{~cm}^{-3}$, respectively, whereas the corresponding values were $4.077 \times 10^{-3}, 3.922 \times 10^{-3}$ and $3.431 \times 10^{-3} \mathrm{~cm} \mathrm{~s}^{-1}$, respectively, at a rainfall intensity of $50 \mathrm{~mm} \mathrm{~h}^{-1}$. In other words, the rainfall infiltration velocity due to the increase in rainfall per unit of time in the soil layer was faster when the rainfall intensity was greater.

Based on the column test result, the velocity of the wetting front (i.e., the rainfall infiltration velocity) was observed to increase with increasing rainfall intensity. In addition, when the unit weight of soil was $1.10,1.21$ and $1.35 \mathrm{~g} \mathrm{~cm}^{-3}$, the rainfall infiltration velocity was $2.143 \times 10^{-3}$ and $4.077 \times 10^{-3} \mathrm{~cm} \mathrm{~s}^{-1}$ with rainfall intensities of 20 and $50 \mathrm{~mm} \mathrm{~h}^{-1}$, respectively, and a unit weight of $1.10 \mathrm{~g} \mathrm{~cm}^{-3}$. These velocities were $2.06 \times 10^{-3}$ and $3.92 \times 10^{-3} \mathrm{~cm} \mathrm{~s}^{-1}$ at a unit weight of $1.21 \mathrm{~g} \mathrm{~cm}^{-3}$ and $1.69 \times 10^{-3}$ and $3.43 \times 10^{-3} \mathrm{~cm} \mathrm{~s}^{-1}$ at a unit weight of $1.35 \mathrm{~g} \mathrm{~cm}^{-3}$. Thus, the rainfall infiltration velocity tends to decrease with in-
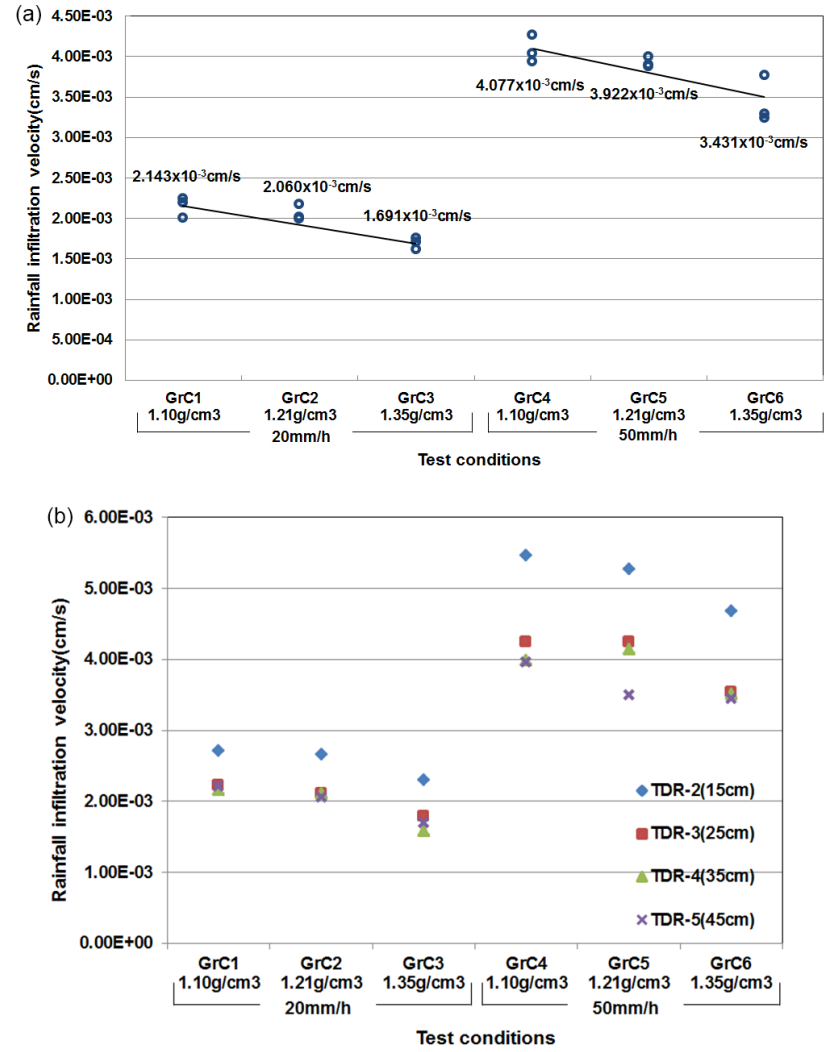

Figure 8. Rainfall infiltration velocity of the weathered granite soil under various conditions. (a) Rainfall infiltration velocity under each rainfall and unit weight soil condition and (b) rainfall infiltration velocity at each depth.

creasing soil unit weights (Fig. 8a, Table 4). This trend is thought to be caused by decreases in the coefficient of permeability in accordance with Darcy's law, in which groundwater flow is affected by the effective pores in the form of decreases in the rainfall infiltration velocity with increases in the unit weight ( $\mathrm{Ng}$ and Shi, 1998). According to the results of permeability tests using 27 soil samples which were collected in the study area, the values of the saturated hydraulic conductivity are distributed between $1.38 \times 10^{-3}$ and $7.16 \times 10^{-3} \mathrm{~cm} \mathrm{~s}^{-1}$. Distribution range of the saturated hydraulic conductivity is similar to the range of rainfall infiltration velocity which is measured by the column tests. The rainfall infiltration velocity decreases with increasing soil depth (Fig. 8b), likely due to clogging: a portion of the effective pores become blocked as many fine grains move downward with the infiltrating rainwater (Kwon et al., 2004). In addition, denser soil with increasing depth following the elapse of time may partially affect the results. The rainfall infiltration velocity slows as pore sizes are reduced, and the coefficient of permeability decreases as the soil becomes denser.

However, under all test conditions, TDR-1 yielded a rainfall infiltration velocity of $6.329 \times 10^{-3}$ 
Table 4. Rainfall infiltration velocity in each test conditions.

\begin{tabular}{llcc}
\hline & Test conditions & $\begin{array}{c}\text { Rainfall } \\
\text { infiltration } \\
\text { velocity } \\
\left(\mathrm{cm} \mathrm{s}^{-1}\right)\end{array}$ & $\begin{array}{c}\text { Porosity } \\
(\%)\end{array}$ \\
\hline \multirow{5}{*}{ Weathered } & $\mathrm{GrC} 1\left(20 \mathrm{~mm} \mathrm{~h}^{-1}, 1.10 \mathrm{~g} \mathrm{~cm}^{-3}\right)$ & $2.143 \times 10^{-3}$ & 57.3 \\
granite soils & $\mathrm{GrC} 2\left(20 \mathrm{~mm} \mathrm{~h}^{-1}, 1.21 \mathrm{~g} \mathrm{~cm}^{-3}\right)$ & $2.060 \times 10^{-3}$ & 53.0 \\
& $\mathrm{GrC} 4\left(50 \mathrm{~mm} \mathrm{~h}^{-1}, 1.35 \mathrm{~g} \mathrm{~cm}^{-3}\right)$ & $1.691 \times 10^{-3}$ & 47.6 \\
& $\mathrm{GrC} 5\left(50 \mathrm{~mm} \mathrm{~h}^{-1}, 1.21 \mathrm{~g} \mathrm{~cm}^{-3}\right)$ & $4.077 \times 10^{-3}$ & 57.3 \\
& GrC6 $\left(50 \mathrm{~mm} \mathrm{~h}^{-1}, 1.35 \mathrm{~g} \mathrm{~cm}^{-3}\right)$ & $3.922 \times 10^{-3}$ & 53.0 \\
\hline
\end{tabular}

$1.670 \times 10^{-2} \mathrm{cms}^{-1}$, which was fast compared to the velocity at the remaining sensors of $1.582 \times 10^{-3}$ $5.468 \times 10^{-3} \mathrm{~cm} \mathrm{~s}^{-1}$. This result contrasts sharply from the velocity values in the overall test results. Therefore, the results of TDR-1 were excluded from the calculation of average rainfall infiltration velocity because the test results were determined to be unreliable. The inconsistency in rainfall infiltration velocity was induced by the column sample molding process. This error was associated with the level of precision in achieving the target unit weight because the consolidation was performed only by vibration and not by pouring the sample outside of the column in the uppermost layer.

\section{Application of the proposed model to the regional study area}

The proposed model was applied to assess the feasibility of the model and to develop a regional landslide susceptibility map. For that purpose, we acquired information regarding the landslide inventory, digital topographic data and strength parameters of the slope materials based on field investigation and laboratory tests. We then analyzed the study area, and the results of the susceptibility analysis were compared with the landslide inventory for validation. The process was performed in a geographic information system (GIS) environment because GIS is an effective spatial data-processing tool over broad areas. The study area was divided into pixels measuring $10 \mathrm{~m} \times 10 \mathrm{~m}$, and then, the input data were converted to a grid with cells measuring $10 \mathrm{~m} \times 10 \mathrm{~m}$ using GIS.

\subsection{Spatial database construction and landslide location detection}

The proposed model required several input parameters, which could be obtained from digital topographic data in the GIS environment, geotechnical field work and laboratory tests. To obtain the geomorphologic attributes of the study area, a digital elevation model (DEM) with a $10 \mathrm{~m}$ resolution was constructed using 1:5000-scale topographic maps, and
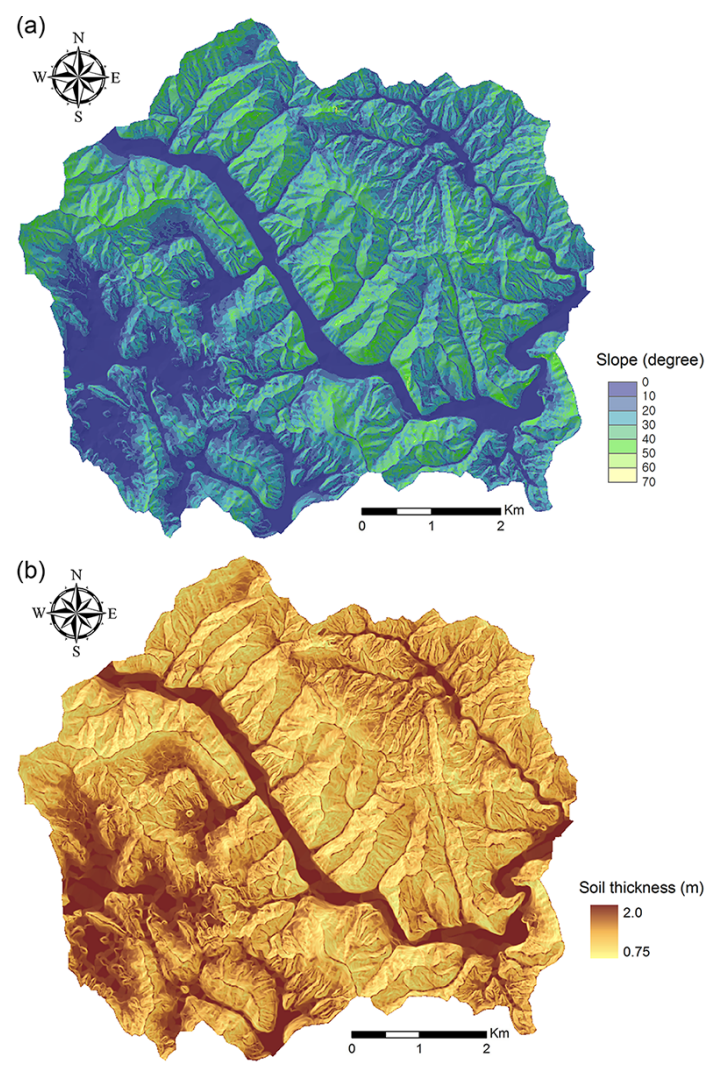

Figure 9. Map showing the distribution of topographic parameters. (a) Slope angle and (b) soil thickness.

the slope gradient was calculated using the DEM (Fig. 9a). The soil thickness in the study area was evaluated using the $Z$ model proposed by Saulnier et al. (1997). It has been known that the performance of this topography-based model is less satisfactory compared with other empirical models. However, in this study, any field measurements of soil thickness were not available, and only limited information, such as topography data and ranges of soil thickness value for each soil type, was provided in the study area. Therefore, the $Z$ model, which is one of the topography-based models, was 
adopted since this model could evaluate the soil thickness in the broad study area with the limited information. In the $Z$ model, the soil thickness was estimated using a linear relationship between soil thickness and elevation and therefore, the minimum and maximum values for soil thickness and elevation were required. The ranges and mean values of the soil thickness for each soil type in the study area were acquired from $1: 25000$-scale digital soil maps produced by the National Institute of Agricultural Science (http://soil.rda.go.kr). Then the soil thickness was evaluated using the $Z$ model and the elevation value and used as the soil depth in the proposed model in Eq. (8) (Fig. 9b). In addition, a geological map was used to model the contributing lithology (Fig. 10).

In this study, the geotechnical soil parameters were obtained from laboratory tests on samples from the study area. Soil samples were collected from the landslide locations in the granite area because the landslides have occurred primarily in this area. From 16 different sampling locations, undisturbed soil samples were collected using a columnar ring sampler at a depth of $50 \mathrm{~cm}$ from the surface, and at each sampling location, three soil samples were obtained for the laboratory tests. A total of 30 direct shear tests were performed to obtain the shear strength parameters, namely, the cohesion and internal friction angle. However, because the number of samples for shear strength testing was limited, Kriging was used to construct the thematic map of the cohesion and friction angle in the study area (Fig. 11a and b). The coefficient of hydraulic conductivity (Fig. 11c) and the unit weights (Fig. 11d) of the soils were also obtained from the laboratory tests.

As noted above, in the proposed model, the factor of safety was calculated using the saturation depth ratio of the soil, based on quasi-dynamic wetness index theory, to evaluate the effect of rainfall infiltration into unsaturated soil. The saturation depth ratio can be determined based on the rainfall infiltration velocity, which can be obtained from the results of the soil column tests. The soil column tests were performed under various test conditions of rainfall intensity, rainfall duration and soil unit weight. The study area experienced heavy rainfall during the period of 10-12 August 1998; the average rainfall intensity in the study area was $20 \mathrm{~mm} \mathrm{~h}^{-1}$ and the total amount of accumulated rainfall was approximately $280 \mathrm{~mm}$. Therefore, based on the soil column tests, the rainfall infiltration velocity was evaluated based on the test conditions of a $20 \mathrm{~mm} \mathrm{~h}^{-1}$ rainfall intensity and a $14 \mathrm{~h}$ rainfall duration. As shown in Fig. 12, the rainfall infiltration velocities corresponding to three unit weights of soil $(1.10,1.21$, $1.35 \mathrm{~g} \mathrm{~cm}^{-3}$ ) at a $20 \mathrm{~mm} \mathrm{~h}^{-1}$ rainfall intensity were obtained from the soil column tests, and a linear regression of the rainfall infiltration velocity was obtained. The infiltration velocities in each soil were determined based on the linear regression model and were used to calculate the factor of safety.

In addition, the landslide locations were obtained from aerial photographic analysis and a complementary field survey. Aerial photographs with a ground resolution of $50 \mathrm{~cm}$,

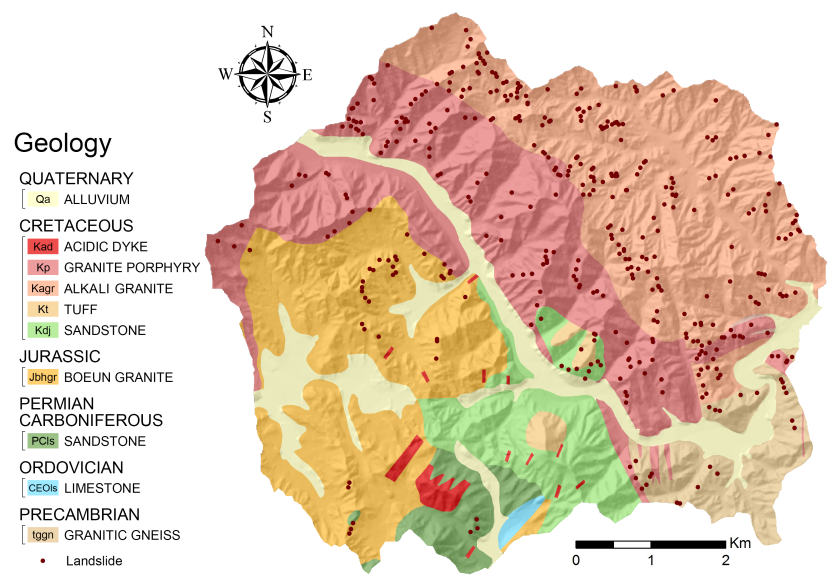

Figure 10. Geological map and location of landslides.

obtained from Samah Aerial Survey Co. Ltd, were used. A total of 418 landslides were mapped (Fig. 10).

\subsection{Evaluation of the model performance}

In landslide susceptibility analysis, model validation is a fundamental step in determining the model performance. An ideal landslide susceptibility map simultaneously maximizes the agreement between known and predicted landslide locations and minimizes the area outside the known landslide locations that is predicted to be unstable (Godt et al., 2008). Therefore, in this study, a receiver operating characteristics (ROC) graph was used to assess the performance of the models because the ROC graph provides a diagnostic test that may be used to distinguish between two classes (true class and modeled class) of events (Swets, 1988; Fawcett, 2006). In ROC analysis, true class instances (observation or landslide occurrence) are compared with modeled class instances (landslide prediction) using a confusion matrix. The observations are classified as positive or negative depending on whether they indicate occurrence or nonoccurrence of a landslide. Therefore, the grid-based prediction results of landslide susceptibility obtained from the proposed analysis could be compared with the landslide inventory. Predictions are classified as yes or no depending on whether they predicted "unstable" or "stable" conditions (Cepeda et al., 2010). Therefore, the grid-based prediction results of landslide susceptibility obtained from the proposed analysis could be compared with the landslide inventory, and one of four outcomes was assigned to each grid cell. If the cell was predicted to be unstable and coincided with a landslide in the inventory, it was counted as a true positive (TP). In contrast, if the cell was predicted to be unstable and did not coincide with a landslide location, it was counted as a false positive (FP). If the cell was predicted to be stable and was outside a known landslide location, it was counted as a true negative (TN), and if it coincided with a landslide occurrence, it 

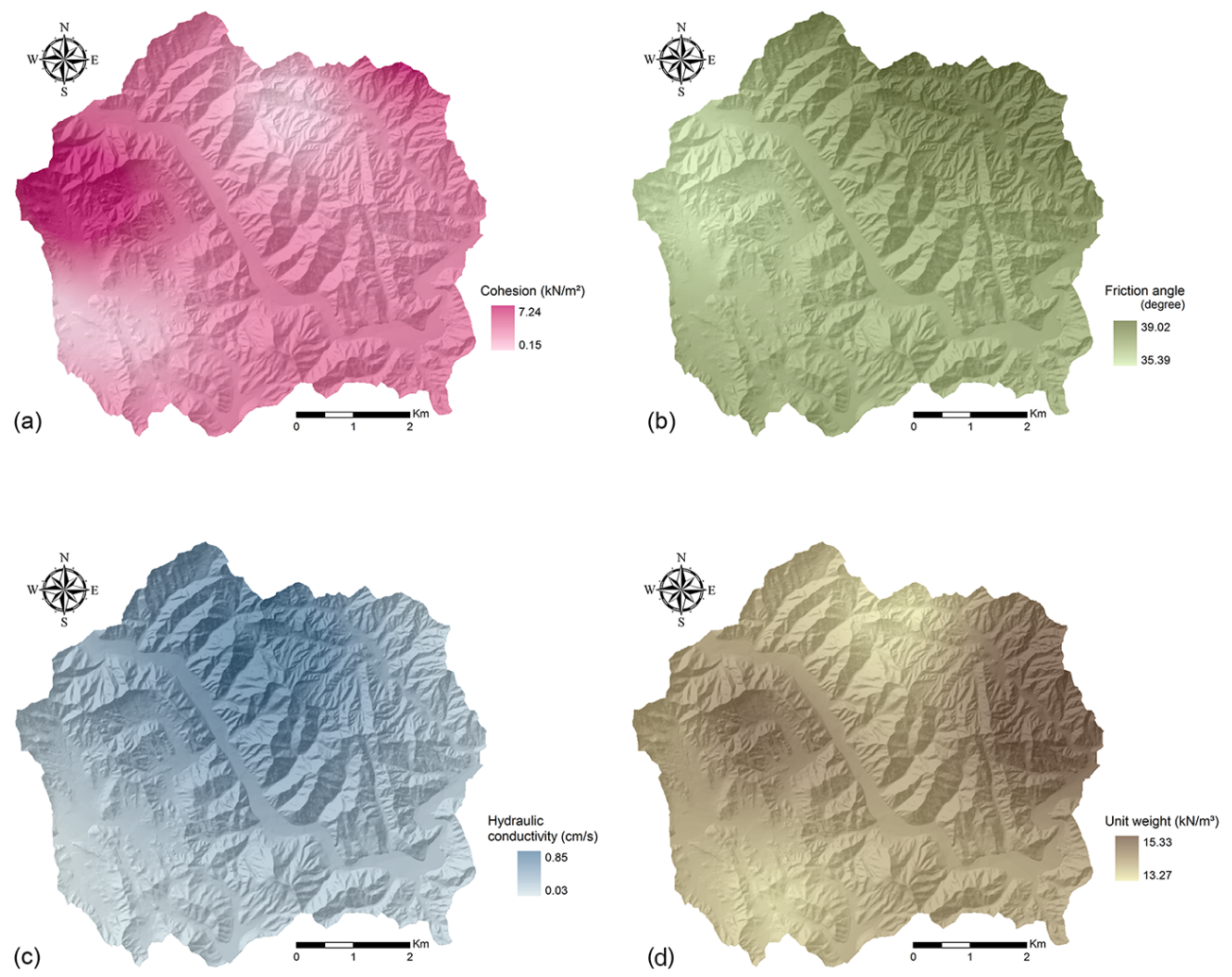

Figure 11. Map showing the distribution of geotechnical soil parameters. (a) Cohesion, (b) friction angle, (c) hydraulic conductivity and (d) unit weight.

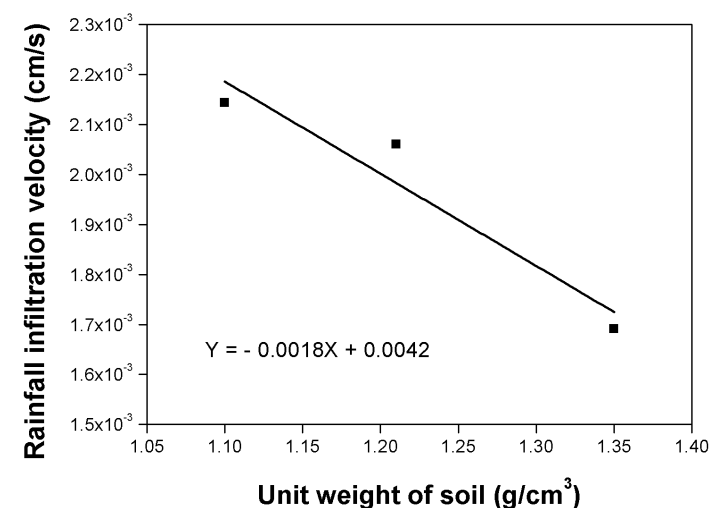

Figure 12. Rainfall infiltration velocity and unit weight of soils.

was counted as a false negative (FN) (Fawcett, 2006; Godt et al., 2008; Cepeda et al., 2010).

Two important measures of model performance (rates of TPs and FPs) are commonly used for model validation. The true-positive rate (TPR) is the ratio of the number of TPs to the total number of positives, and the false-positive rate (FPR) is the ratio of the number of FPs to the total number of negatives. These two metrics were used to plot the ROC graph, which is a two-dimensional graph in which the TPR is plotted on the y-axis and the FPR is plot- ted on the $x$ axis. Model results that plot toward the upper left corner of the graph are generally considered superior (Godt et al., 2008). An acceptance prediction requires that TPR/FPR $>1.0$, and larger values of the TPR/FPR ratio indicate better predictive performance of the model. Another statistical parameter of model performance is its accuracy (ACC). ACC is assessed by analyzing the agreement between the model results and observed data. Therefore, ACC is the ratio of TPs plus TNs to the total positives and negatives.

\subsection{Results of regional analysis}

Figure 13 shows a map of the spatial distribution of the factor of safety using the proposed approach. In the concept of factor of safety, a value of FS $=1.0$ is considered to be the critical value for evaluating the stability of the slope; i.e., a factor of safety of less than 1.0 implies an unstable slope.

In the results of the model analysis, 85856 of the 437691 cells were assigned a factor of safety of less than 1.0. In other words, $19.6 \%$ of the study area was classified as unstable. In addition, 267 of the 418 cells where actual landslides occurred had a factor of safety less than 1.0. Thus, $63.9 \%$ of actual landslides (or the mapped landslides in the inventory map) were classified as unstable, meaning that the TPR, which is the ratio of the number of correctly predicted 


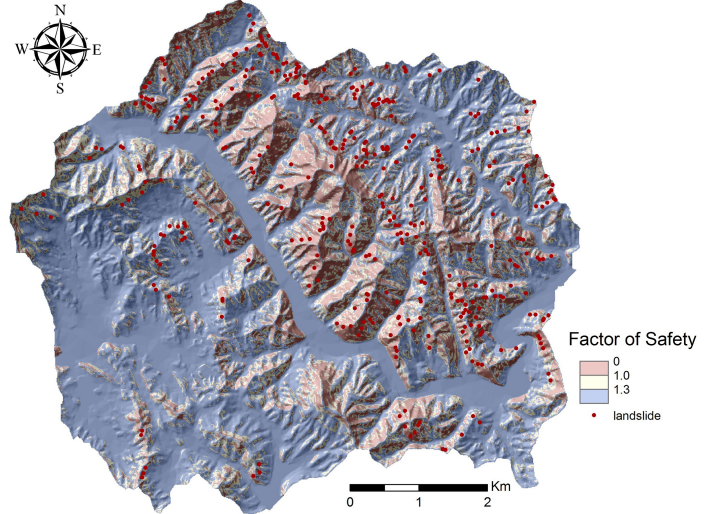

Figure 13. Map showing the factor of safety predicted using the proposed model.

landslide cells (TPs) to the total number of landslide occurrence cells (positives), was 0.639 . In addition, $19.6 \%$ of nonlandslide cells were classified as unstable, which means that the FPR was 0.196 . The TPR/FPR ratio was 3.26 , and the ACC was $80.4 \%$.

\section{Comparison of the proposed approach and previous analyses}

To compare the results of the proposed approach and previous analyses, an analysis using the steady-state model applied by several authors previously (Dietrich et al., 2001; Borga et al., 2002; Huang et al., 2006, 2007) was also conducted. In the steady-state model, the porewater pressure can be calculated assuming a hydrogeologic steady state, with the depth of saturated soil being sufficient to sustain a lateral discharge proportional to the specific contributing area (upslope area per unit contour length) (Pack et al., 2001). Therefore, the infinite slope model, which assumed steady-state shallow subsurface flow, was used to evaluate the factor of safety using the following equation:

$$
\begin{aligned}
\mathrm{FS} & =\frac{c^{\prime}+\left[\gamma \cdot z-m \cdot \gamma_{\mathrm{w}} \cdot z\right] \cos ^{2} \alpha \tan \phi^{\prime}}{\gamma \cdot z \cdot \sin \alpha \cos \alpha} \\
& =\frac{c^{\prime}+\left[\gamma \cdot z-\min \left(\frac{R}{T} \cdot \frac{a}{\sin \alpha}, 1.0\right) \cdot \gamma_{\mathrm{w}} \cdot z\right] \cos ^{2} \alpha \tan \phi^{\prime}}{\gamma \cdot z \cdot \sin \alpha \cos \alpha},
\end{aligned}
$$

where $m$ is the ratio of the groundwater level to the soil depth $\left(=\frac{h_{\mathrm{W}}}{z}\right), R$ is the rainfall intensity, $T$ is the soil transmissivity, which is the soil hydraulic conductivity times the soil thickness and $a$ is the specific contributing area (Beven and Kirkby, 1979; O'Loughlin, 1986; Montgomery and Dietrich, 1994; Hsu, 1998; Dietrich et al., 2001; Borga et al., 2002; Huang et al., 2006, 2007; Reid et al., 2007).

Figure 14 shows a map of the factor of safety using the coupled infinite slope model and steady-state hydrological model. In the results, $44.9 \%$ of the study area was classified as unstable, which means that a large portion of the study

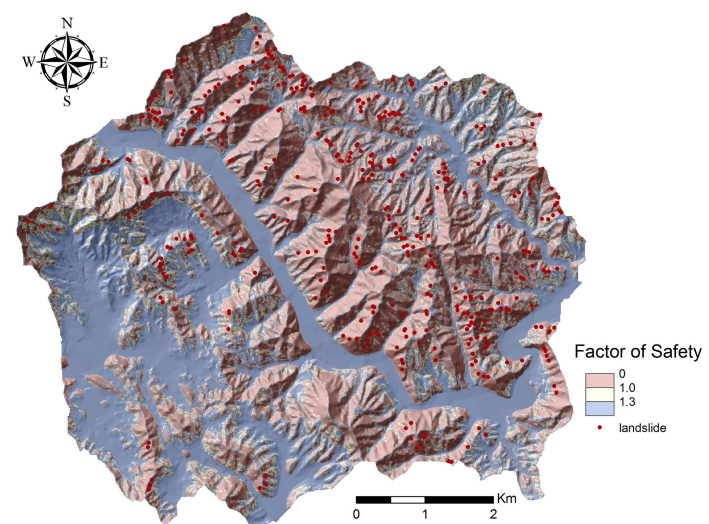

Figure 14. Map showing the factor of safety predicted using the steady-state hydrological model.

area was predicted as being unstable. In addition, 398 of the 418 actual landslide cells were classified as unstable (i.e., factor of safety less than 1.0); thus, the TPR was 0.952 , and the FPR was 0.448 . The TPR/FPR ratio and ACC were 2.12 and $55.2 \%$, respectively. Consequently, the steady-state approach resulted in a larger portion of study area being classified as unstable, which yielded a low TPR/FPR ratio and ACC. Therefore, the proposed approach produced better performance than the steady-state approach model.

\section{Conclusions}

Since landslides in Korea are typically shallow landslides, which are related to rainfall infiltration, we have proposed a modified equation of infinite slope analysis by applying the concept of the saturation depth ratio to analyze the slope stability as a function of rainfall falling on a slope. In this study, a rainfall infiltration test in unsaturated soil was performed using a column to understand the effects of the saturation depth ratio variation following rainfall infiltration from the ground surface into the unsaturated zone. Based on the test results, it was possible to acquire rainfall infiltration velocity dependent on rainfall conditions and unit weight conditions of the soil. The results indicate that the rainfall infiltration velocity, due to the increase in rainfall per unit of time in the soil layer, increased with increasing rainfall intensity. In addition, based on the change in rainfall infiltration velocity with increases in the unit weight of soil, the rainfall infiltration tended to decrease with an increasing soil unit weight. The proposed model was applied to assess its feasibility and to develop a regional landslide susceptibility map using GIS over broad areas. The results of the analysis indicate that $19.6 \%$ of the study area had a factor of safety less than 1.0, meaning that these areas are unstable. In addition, the TPR and FPR were 0.639 and 0.196 , respectively. The TPR/FPR ratio was 3.26 , and the ACC was $80.4 \%$. A comparison of the results of the proposed approach with the re- 
sults of the previous steady-state model was also performed. In the results, $44.9 \%$ of the study area was classified as unstable and the TPR was 0.952 and the FPR was 0.448 . The TPR/FPR ratio and ACC were 2.12 and $55.2 \%$, respectively. Consequently, the steady-state approach model resulted in a low TPR/FPR ratio and ACC and therefore, the proposed approach presented in this study displayed better performance than the steady-state approach.

Acknowledgements. This research was supported by the Public Welfare \& Safety Research Program through the National Research Foundation of Korea (NRF) funded by the Ministry of Science, ICT \& Future Planning (grant nos. 2012M3A2A1050983 and 2012M3A2A1050984). This research was also partly supported by the Basic Research Project (Technology Development of Landslide Rapid Detection based on a Real-time Monitoring) of the Korea Institute of Geoscience and Mineral Resources (KIGAM) funded by the Ministry of Science, ICT \& Future Planning.

Edited by: F. Catani

Reviewed by: two anonymous referees

\section{References}

Aleotti, P.: A warning system for rainfall-induced shallow failures, Eng. Geol., 73, 247-268, 2004.

Beven, K. J. and Kirkby, M. J.: A physically-based, variable contributing area model of basin hydrology, Hydrol. Sci. Bull., 24, 43-69, 1979.

Borga, M., Dalla Fontana, G., Gregoretti, C., and Marchi, L.: Assessment of shallow landsliding by using a physically based model of hillslope stability, Hydrol. Process., 16, 2833-2851, 2002.

Cannon, S. H. and Ellen, S. D.: Rainfall conditions for abundant debris avalanches, San Francisco Bay region, California, Calif. Geol., 38, 267-272, 1985.

Cepeda, J., Chavez, J. A., and Martinez, C. C.: Procedure for the selection of runout model parameters from landslide back analyses: application to the Metropolitan area of San Salvador, El Salvador, Landslides, 7, 105-116, 2010.

Crosta, G.: Regionalization of rainfall thresholds: an aid to landslide hazard evaluation, Environ. Geol., 35, 131-145, 1998.

Dietrich, W. E., Bellugi, D., and Real De Asua, R.: Validation of the shallow landslide model, SHALSTAB, for forest management, Water Sci. Appl., 2, 195-227, 2001.

Fawcett, T.: An introduction to ROC analysis, Pattern Recog. Lett., 27, 861-874, 2006.

Fourie, A. B.: Predicting rainfall-induced slope instability, Proc. Inst. Civil Eng. Geotech. Eng., 119, 211-218, 1996.

Fourie, A. B., Rowe, D., and Blight, G. E.: The effect of infiltration on the stability of the slopes of a dry ash dump, Geotechnique, 46, 1-13, 1999.

Fredlund, D. G. and Rahardjo, H.: Soil mechanics for unsaturated soils, Wiley, New York, p. 517, 1993.

Godt, J. W., Baum, R. L., Savage, W. Z., Salciarini, D., Schulz, W. H., and Harp, E. L.: Transient deterministic shallow land- slide modeling: requirements for susceptibility and hazard assessments in a GIS framework, Eng. Geol., 102, 214-226, 2008.

Green, W. H. and Ampt, G. A.: Studies on soil physics: 1. The flow of air and water through soils, J. Agr. Sci., 4, 1-24, 1911.

Hammond, C., Hall, D., Miller, S., and Swetik, P.: Level I stability analysis (LISA) documentation for version 2, General Technical Report INT-285, USDA Forest Service Intermountain Research Station, Ogden, UT, p. 121, 1992.

Hsu, M. L.: A grid based model for predicting shallow landslides: A case study in Linkou, Taipei, EOS Trans. AGU, 79, 25, 1998.

Huang, J.-C., Kao, S.-J., Hsu, M.-L., and Lin, J.-C.: Stochastic procedure to extract and to integrate landslide susceptibility maps: an example of mountainous watershed in Taiwan, Nat. Hazards Earth Syst. Sci., 6, 803-815, doi:10.5194/nhess-6-8032006, 2006.

Huang, J.-C., Kao, S.-J., Hsu, M.-L., and Liu, Y.-A.: Influence of Specific Contributing Area algorithms on slope failure prediction in landslide modeling, Nat. Hazards Earth Syst. Sci., 7, 781-792, doi:10.5194/nhess-7-781-2007, 2007.

Kim, J., Jeong, S., Park, S., and Sharma, J.: Influence of rainfallinduced wetting on the stability of slopes in weathered soils, Eng. Geol., 75, 251-262, 2004.

Kim, J., Jeong, S., and Regueiro, R. A.: Instability of partially saturated soil slopes due to alteration of rainfall pattern, Eng. Geol., 147-148, 28-36, 2012.

Kim, S. K., Ryu, J. H., and Song, J. K.: Measurements of soil-water characteristics for different unsaturated soils, J. Korean Geotech. Soc., 12, 139-152, 1996.

Kim, W. Y. and Chae, B.-G.: Characteristics of Rainfall, Geology and Failure Geometry of the Landslide Areas on Natural Terrains, Korea, J. Eng. Geol., 19, 329-342, 2009.

Kwon, H.-M., Kim, C.-Y., Park, Y.-H., Chung, C.-K., and Kim, M.M.: Experimental investigation of seepage properties on weathered residual soils, J. Korean Geotech. Soc., 20, 75-82, 2004.

Lee, S. G. and de Freitas, M. H.: A revision of the description and classification of weathered granite and its application to granites in Korea, J. Eng. Geol., 22, 31-48, 1989.

Montgomery, D. R. and Dietrich, W. E.: A physically-based model for the topographic control on shallow landsliding, Water Resour. Res., 30, 1153-1171, 1994.

Muntohar, A. S. and Liao, H.-J.: Rainfall infiltration: infinite slope model for landslides triggering by rainstorm, Nat. Hazards, 54, 967-984, 2010.

$\mathrm{Ng}, \mathrm{C} . \mathrm{W}$. W. and Shi, Q.: Influence of rainfall intensity and duration on slope stability in unsaturated soils, Q. J. Eng. Geol., 31, 105$113,1998$.

O'Loughlin, E. M.: Prediction of surface saturation zones in natural catchments by topographic analysis, Water Resour. Res., 22, 794-804, 1986.

Pack, T. T., Tarboton, D. G., and Goodwin, C. N.: Assessing terrain stability in a GIS using SINMAP, 15th Annual GIS Conference, GIS 2001, Vancouver, BC, 2001.

Park, K.-B., Chae, B.-G., and Park, H.-J.: Analysis of rainfall infiltration velocity in unsaturated soils under both continuous and repeated rainfall conditions by an unsaturated soil column test, J. Eng. Geol., 21, 133-145, 2011.

Rahardjo, H., Lim, T. T., Chang, M. F., and Fredlund, D. G.: Shear strength characteristics of a residual soil, Can. Geotech., 32, 6077, 1995. 
Reid, M. E., Ellen, S. D., Brien, D. L., Fuente, J., Falls, J. N., Hicks, B. G., and Johnson, E. C.: Predicting debris slide locations in northwestern California, USDA Forest Service Gen Tech Rep. PSW-GTR-194, USDA Forest Service, Albany, CA, 2007.
Saulnier, G. M., Beven, K. J., and Obled, C.: Including spatially variable effective soil depths in TOPMODEL, J. Hydrol., 202, 158-172, 1997.

Swets, J.: Measuring the accuracy of diagnostic systems, Science, 240, 1285-1293, 1988 . 